\title{
THE IMPLEMENTATION OF FAMILY PRESERVATION SERVICES: PERSPECTIVES OF SOCIAL WORKERS AT NGOS
}

\section{Marianne Strydom}

\section{INTRODUCTION}

According to the White Paper for Social Welfare (1997), one of the goals of child and family welfare services in social work is to maintain and strengthen the functioning of high-risk families in order to enhance their physical, social and emotional development. Family preservation is a strategy to empower families to enhance the optimal development of children and to prevent the statutory removal of children from their families. To avoid this removal the focus of social workers, when rendering family preservation services, must first be on prevention services, then on early intervention services and last on statutory services in order to implement a developmental social service policy (Department of Social Development, 2006:20, Ministry for Welfare and Population Development, 1997:62).

Within this context the intention of this article is to give a literature overview of the obstacles to the implementation of family preservation services with a preventative focus, as well as to explore the perspectives of social workers at NGOs on the implementation of policy documents such as the White Paper for Social Welfare (Ministry for Welfare and Population Development, 1997:62) and the Integrated Service Delivery Model for Improved Developmental Social Services (ISDM) in terms of the focus on preventative work. The article will also identify the views of social workers on where the emphasis in terms of the different levels of service rendering according to the ISDM (Department of Social Development, 2006:20) was placed in their situation. Their perspectives on the structural problems that were experienced during the implementation of family preservation services with a preventative focus are discussed. Finally the views of social workers concerning the ways in which they could work more preventatively are identified.

\section{METHODOLOGY AND RESEARCH DESIGN}

An empirical investigation was undertaken in the Western Cape Metropolitan area and surrounding areas, and a combination of quantitative and qualitative approaches was used (Fouché \& De Vos, 2005:133-134). This research can be classified as exploratory and descriptive research, as defined by De Vos, Strydom, Fouché and Delport (2002:139) and Grinnell and Williams (1990:150), as these designs are suitable for qualitative as well as quantitative methods of research (Fouché \& De Vos, 2005:134).

For purposes of this study the population (De Vos et al., 2002:198; Grinnell \& Williams, 1990:118) consisted of all the social workers who rendered family preservation services at three Non-Governmental Family Organisations (NGOs) in the Western Cape Metropolitan and surrounding areas. The study was limited to the Western Cape Metropolitan area and its surrounds (Cape Town, Bellville, Kuils River, Strand, Somerset West, Stellenbosch) as this area was geographically accessible to the researcher. Purposive selection according to the non-probability selection classification (De Vos et al., 2002:204,207; Grinnell \& Williams, 1990:126,127; Strydom, 2005:201,202) was used for sampling, as only social workers who had been delivering family prevention services for at least a year were included in the study. The population consisted of $61(\mathrm{~N}=61)$ social workers. 
A self-administered semi-structured questionnaire (De Vos et al., 2002:169) was used to gather quantitative and qualitative data. The questions in the semi-structured questionnaire were based on the literature study, and applicable open and closed questions (Rubin \& Babbie, 2007:111) were developed. Thus a deductive method (Grinnell, 1988:327-328) was followed. The semi-structured questionnaire was tested in March 2008 by involving four social workers in a pilot study so that the necessary changes could be made before data collection took place (De Vos et al., 2002:172; Rubin \& Babbie, 2007:118).

The questionnaires were distributed to the various area managers, regional representatives and offices of the three organisations involved in the research. From there they were distributed to the social workers for completion. Fifty-eight $(n=58)$ of the $61(\mathrm{~N}=61)$ respondents completed the questionnaire, which means that a response of $95 \%$ was obtained from the population.

The quantitative data were processed by computer, while the qualitative data were processed by hand. After all the information had been processed, the data provided by the respondents were discussed further by a focus group (Strydom, 2005:299,300). The advantage of using a combination of techniques (questionnaires and a focus group), according to Weyers, Strydom and Huisamen (2008:207), is that data can be compared and similarities as well as incongruities can be noted.

Participants were identified for inclusion in the focus group discussions according to purposive selection (Strydom, 2005:201,202) by inviting two social workers from each of the three organisations involved in the investigation. The composition of the focus group was in compliance with the criteria in the literature (Strydom, 2005:303-307), which state that five or six members were considered suitable to form a focus group. The focus group was further homogenous in the sense that all the participants were female and were involved in the delivery of family preservation services, thus enhancing group discussions. Only one focus group session was held as the information generated during this two-hour discussion largely repeated or supported the data already collected from the semi-structured questionnaire.

The interview was taped and transcribed and then used to support or further inform the data already gathered by supplying the narratives of focus group members. All information gathered was treated as confidential, in accordance with the ethical code of the social work profession.

\section{BACKGROUND TO THE STUDY}

According to policy documents such as the ISDM (Department of Social Development, 2006:29) and the White Paper for Social Welfare (Ministry of Welfare and Population Development, 1997:62), social work must focus first on preventative services, then on early intervention services and last on statutory services in order to implement a developmental policy for the delivery of social work services. Such a policy underpinning the delivery of social work services means that social workers must concentrate more on delivering preventative rather than restorative services in order to bring about transformation in the welfare system in South Africa.

Some authors (Hochfeld, 2007:89; Lombard, 2007:296; September, 2006:71,66; Sewpaul, 2001:574) argue that certain problems, such as a lack of specific guidelines, leadership and finance, impede the implementation of a developmental social service policy, in turn affecting the establishment of developmental services. This could mean that the desired paradigm shift to preventative services in social service delivery, according to the developmental policy, has not yet taken place effectively. 
It is therefore possible that family preservation services in South Africa are being delivered in inverse order to what is recommended by policy documents (Department of Social Development, 2006:29; Ministry for Welfare and Population Development, 1997), meaning that the focus is still on statutory services instead of on preventative services.

Effective family preservation services are aimed at keeping children safe within their families by stabilising the crisis situation which could result in the removal of children. During intervention, social work services are rendered to improve the coping skills of the family by, amongst other things, strengthening family ties, as well as by improving the family's utilisation of formal and informal resources (Tracy, 1995:980). According to Pecora et al. (1995) and Tracy (1995:980), the aim of these services to families is first on preventative (family support or community work) services, then on therapeutic (family-centred or casework) services, and last on statutory services. These aims correspond with the different levels of service rendering according to the ISDM (Department of Social Development, 2006:20).

For the purpose of this article family preservation services with a focus on prevention are thus defined as services or resources that are available in communities for families, or that are initiated by social workers at NGOs through community work services.

Inadequate family preservation services with a focus on prevention therefore have a direct, limiting effect on statutory services, impeding the establishment of resources for families, such as playgroups, childcare facilities and parental guidance groups. And where preventative services are inadequate, and families are not provided with the community resources needed to prevent the removal of children, statutory services will still dominate.

\section{OBSTACLES TO THE IMPLEMENTATION OF FAMILY PRESERVATION SERVICES WITH A FOCUS ON PREVENTION}

In this section the focus is on a few obstacles as identified in research (Brown \& Neku, 2005; Streak \& Poggenpoel, 2005) which could hamper the implementation of family preservation services with a focus on prevention.

\section{Lack of funds}

In the research of Streak and Poggenpoel (2005:41) NGOs indicated that insufficient funds were the most important obstacle in the way of effective service delivery. Greater pressure was brought to bear on existing funds, because NGOs were expected in programmes to concentrate also on the alleviation and eradication of poverty, while they were already finding it difficult to deliver basic services, such as statutory services, effectively because of financial constraints. An important obstacle was also the fact that NGOs were not compensated by government for the statutory services they rendered. The conclusion was reached that the government funding of NGOs was not in line with their needs and therefore funding was insufficient for social welfare services overall. The result was that organisations struggled to deliver existing services (especially statutory services) and also that service delivery was not expanded.

The fact that insufficient funds affect service delivery was confirmed by September (2007:98), as well as in the National Policy Framework for the Prevention and Treatment of Child abuse, Neglect and Exploitation (Department of Social Development, 2005:20). Streak and Poggenpoel (2005) recommended that the government fund the total costs of statutory services. Should that happen, the NGOs could use the funds they acquired from sponsors to deliver prevention and early intervention services. 


\section{Lack of people power}

A further obstacle to the implementation of preventative social services is a lack of people power, which is linked to the fact that there is insufficient funding of welfare services, especially statutory services. The shortage of social workers to render services has been pointed out by authors (Brown \& Neku, 2005:308; Lombard \& Kleijn, 2006:225; September, 2007:43; September \& Blankenberg, 2004:29) and in official documents (Department of Social Development, 2006:10,11; Department of Social Development, 2005:20). Research (September \& Blankenberg, 2004:28,29) indicated that social workers often had very heavy case loads, varying between 150 and 300 cases. These case loads included cases of child abuse and neglect, substance abuse and ongoing children's court investigations. Shortages of staff, specifically of social workers, as well as inadequate resources in the communities, hamper the delivery of child protection services.

The lack of national standards and norms for the delivery of child protection services, as well as insufficient funds, makes it increasingly difficult for welfare organisations to deliver quality services and to retain their personnel (September, 2006:67). In all sectors dealing with child protection the staff are overworked, underpaid and insufficiently trained. In the NGO sector social workers involved in child protection services leave their posts because of poor remuneration and a lack of work satisfaction to work in other sectors or in positions with better salaries. The delivery of effective services is affected, because this pattern is repeated by new social workers who fill the vacant posts (Department of Social Development, 2005:24). September (2006) duly remarked that it was essential for NGOs involved in the rendering of child and family welfare services to be supplied with appropriate resources, based on a standardised national funding policy. In this way these organisations will be enabled to deliver the critical services which government organisations alone are unable to deliver.

In Streak and Poggenpoel's (2005:41) study NGOs also indicated that they experienced problems with staff turnover as social workers left the organisations after they had gained experience to work for government organisations, where they could earn higher salaries. This lack of people power and sufficient funds in the private sector therefore proved to be important obstacles to the delivery of effective developmental social services during the past 10 years.

\section{Lack of resources in organisations}

A lack of resources such as equipment, supervisors and in-service training was considered an obstacle to the delivery of effective services in Brown and Neku's (2005:309) study. Respondents from both governmental and non-governmental organisations described the demands of the social work profession as overwhelming and often frustrating as the needs of the community were pressing, while the availability of social workers, especially in rural areas, was insufficient. They indicated that there was often little they could do to help people who suffered from a lack of food or finance, and they often wondered how the families would survive. As people in need usually have no form of transport, social workers have to travel along poor roads, and organisations do not always have vehicles to put at their disposal for visiting these communities.

In this regard the ISDM (Department of Social Development, 2006:57) requires that certain basic infrastructure and equipment are needed specifically by social workers, as they are obliged by law to deliver services in a certain manner, and they are subject to disciplinary steps should they fail to carry out their duties in an appropriate manner. On the list of infrastructure vehicles are listed as essential to ensure that clients and communities can be visited. 
The discussion shows that the transformation of the welfare system in South Africa from residual to developmental is affected by obstacles as described above. The lack of funds, people power and resources proves to be an obstacle to effective service delivery.

\section{RESULTS OF THE STUDY}

The results of the study are explained with reference to the research questions which were mainly aimed to determine:

- where the focus was placed in service delivery in respect of family preservation services, in accordance with the ISDM (Department of Social Development, 2006);

- which obstacles were encountered in the implementation of family preservation services with a focus on prevention;

- in which ways the work could be conducted in a more preventative manner.

\section{Profile of respondents and focus group members}

Most (28) of the respondents $(n=58)$ were between the ages of 23 and 29. The majority of the respondents also had between one and four years of work experience, which corresponds with the age group (early adulthood) in which most of the respondents fall. Fifty of the respondents had also been in the service of a family welfare organisation for between one and four years. Family preservation services were thus delivered mostly by young adult workers.

The majority (36) of the respondents were in possession of a four-year degree qualification. Nine respondents had a postgraduate qualification. The rest (9) held a Diploma in Social Work and a three-year degree (3).

Regarding the case load, the majority (35) of respondents had a case load of 100 to 299 families. The minority (22) had a case load of fewer than 100. The average case load per respondent consisted of 126 families, which is higher than that which was found in Kruger's study (1996:61), where the average case load of respondents working in family welfare organisations in the Western Cape was 94.5 families. It is clear that respondents in family welfare organisations in the Western Cape Metropolitan area and surrounds often have large case loads, confirming other South African research findings (September \& Blankenberg, 2004:28,29), where case loads often varied between 150 and 300 cases.

\section{Levels at which family preservation services were delivered}

The respondents were asked for their opinions on where the emphasis was placed on the different levels of service delivery in accordance with the ISDM (2006) in their situations. The results are presented in Figure 1.

According to Figure 1, the opinion of more than half (32 or 55\%) of the respondents was that the emphasis of service delivery was still placed more strongly on statutory services, while 16 considered it to be the second highest. Most of the respondents were thus of the opinion that the emphasis in service delivery regarding family preservation was still on level 3 and level 4 of the figure, i.e. on statutory services and not on preventative services as recommended by ISDM (2006:29). 
FIGURE 1

THE OPINIONS OF RESPONDENTS ON WHERE THE EMPHASIS OF SERVICE DELIVERY WAS PLACED IN THEIR SITUATION

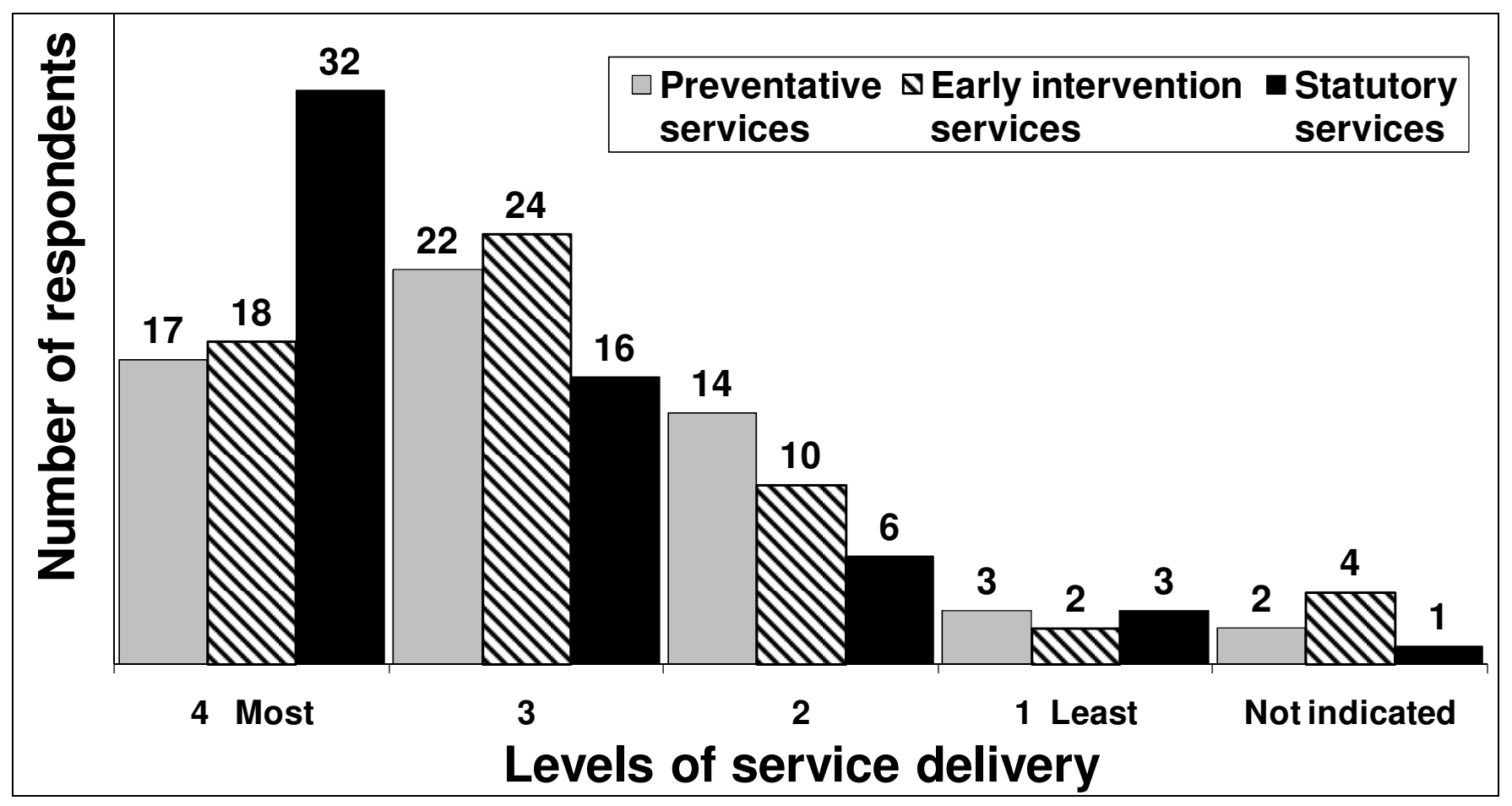

Regarding the delivery of early intervention services (therapeutic services to avoid statutory services), more than a quarter of the respondents (18) indicated that the emphasis of service delivery fell most strongly, after statutory services, on early intervention services. Eighteen of the respondents indicated that early intervention services received the most attention in their situation and 24 considered it to be the second most important. According to the ISDM (Department of Social Development, 2006:29), respondents should deliver early intervention services (therapeutic services) to families in order to avoid statutory services. It was found that most of the respondents in this investigation were of the opinion that in their situation early intervention in fact received more emphasis rather than less.

Preventative services (community work programmes to prevent at risk behaviour), according to respondents, received the least attention. Seventeen respondents indicated that these services enjoyed the most emphasis, while 22 of the respondents felt that the second highest emphasis fell on this aspect. Fourteen respondents felt that the emphasis on preventative services was low.

The conclusion is drawn that preventative or community work programmes at the organisations concerned were still emphasised less than early intervention or statutory services in service delivery.

\section{Obstacles to the delivery of family preservation services with a focus on prevention}

There was an attempt to identify the obstacles that the respondents experienced in their situations when delivering family preservation services with a focus on prevention. They were requested to answer Yes or No. The results are presented in Figure 2. 


\section{OBSTACLES TO THE DELIVERY OF FAMILY PRESERVATION SERVICES WITH} A FOCUS ON PREVENTION

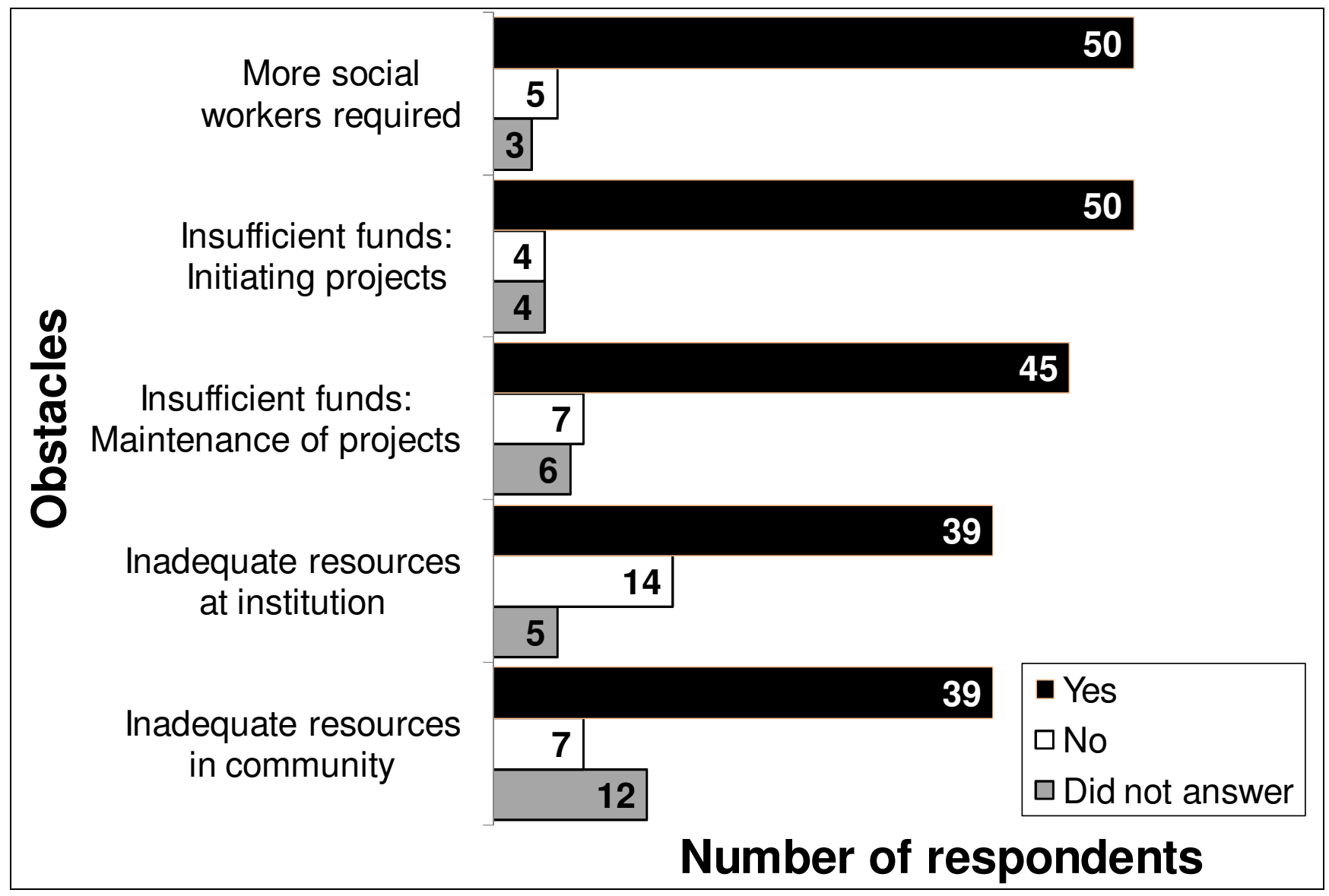

Most (50) of the respondents were of the opinion that an important obstacle was the fact that more social workers were needed. The perspective was thus that there was a shortage of social workers to deliver family preservation services with a focus on prevention.

Insufficient funds for initiating projects were, like the shortage of social workers, considered as an important obstacle by 50 of the respondents. This shortage of funds is also considered an obstacle to the maintenance of projects by quite a number of the respondents, as 45 respondents mentioned it as an obstacle to the delivery of family preservation services with a preventative focus.

These findings confirmed research by Streak and Poggenpoel (2005:41). In their research it was found that NGOs did not have sufficient funds to deliver basic services such as statutory services, and that the expectation of the government that further programmes be implemented placed greater pressure on limited financial resources.

Regarding insufficient resources such as lack of vehicles in the organisations, as well as insufficient resources in the community, the majority (39) of respondents indicated that this was an obstacle. This finding is corroborated by South African research by Brown and Neku (2005:309) in which respondents also indicated that insufficient resources (e.g. lack of vehicles) in the organisation hindered service delivery. 


\section{Opinions regarding the feasibility of service delivery aimed at preventative services}

To determine the perspective of respondents on the delivery of family preservation services with a focus on prevention, the respondents were posed an open question regarding the feasibility of the requirements in policy documents (Integrated Service Delivery Model for Improved Developmental Social Services, 2006; White Paper for Social Welfare, Ministry of Welfare and Population Development, 1997), which state that family preservation services should focus mainly on preventative services. Respondents were for the most part of the opinion that this requirement was difficult to implement in the communities where they were rendering services. Opinions on the feasibility of this requirement were divided into five themes, which are discussed below.

\section{Resources were limited or inaccessible}

The majority (36) of the respondents felt that the resources were limited in communities because of excessive demand. One respondent remarked: "The community is very poor and the resources are too few to meet the huge demand of the community or become exhausted. The minority of community members benefit from the resources available." ["Die gemeenskap is gedompel in armoede en die bronne is te min om in die groot aanvraag van die gemeenskap te voorsien of word uitgeput. Die minimum gemeenskapslede vind baat by die bronne beskikbaar."]

Another aspect that emerged was that resources were inaccessible to families because, for example, the family did not have the financial ability to utilise the resource, and the organisation could not support the family financially. Resources could also only be reached within normal office hours, which made them inaccessible to working parents. A respondent remarked: "Most preventative resources in the community have financial implications which put them beyond the reach of a large section of the client system. Free services cannot effectively meet the demand." ["Die meeste voorkomende bronne in die gemeenskap het finansiële implikasies wat dit buite die bereik van "n groot deel van die kliëntsisteem plaas. Gratis dienste kan nie die aanvraag effektief hanteer nie."]

From the above it is obvious that the high-risk communities served by the three family welfare organisations in the Western Cape Metropolitan and surrounding areas, as described in the literature (Coulton, Korbin \& Su, 1999:1034, Garbarino \& Kostelny, 1992:461), were characterised by insufficient resources and services. The result of this situation was that, despite policy requirements, not enough resources existed in the communities for utilisation by families. These circumstances place constraints upon the delivery of preventative services that are supposed to prevent the need for statutory services.

\section{Workload was heavy}

The fact that the work load was heavy was given by 21 of the respondents as a reason for why it was difficult to render preventative services. One respondent remarked: "The work load is too high and it sometimes feels as if you are just responding to crises (putting out fires)." ["Die werklading is te hoog en voel dit soms of jy net "vure doodslaan"'.) Another respondent said: "Too few social workers with too high case loads are expected to create and maintain these resources - where are they supposed to find the time?!” Aspects that came to light regarding the high work loads were the turnover of social workers as well as the fact that social workers should not be expected to render preventative or community work services. Other staff members, such as community developers, should be appointed to render these services. 
The finding that work loads were heavy correlates with an earlier finding in this study, namely that the perception of the respondents was that the shortage of social workers was an important obstacle to the rendering of family preservation services with a focus on prevention.

\section{Clients did not co-operate}

The fact that clients did not co-operate was mentioned by a third (18) of the correspondents as an aspect which hampered the practicability of preventative service delivery.

\section{Insufficient funds in the organisation to maintain programmes}

A minority (9) of the respondents mentioned insufficient funds in the organisation to maintain programmes as a factor affecting preventative service delivery. This response of the respondents was associated with the fact that clients did not attend programmes because of insufficient resources such as transport, or because organisations apparently did not have funds to provide transport, organise child care facilities, or supply refreshments during programmes. One respondent noted: "Programmes are poorly attended unless refreshments and entertainment are provided." ["Programme word swak bygewoon, tensy baie voedsel en vermaak beskikbaar gestel word."]

The fact that incentives such as transport, child care facilities and meals must be offered to motivate clients to attend programmes has been confirmed by research in New Zealand, the United Kingdom and the USA (Bell, 2005; Nicholson, Brenner \& Fox, 1999; Sanders \& Cann, 2002). In these studies it was found that the success of parent-education programmes depended on the extras offered to motivate attendance. The deduction can be made that it is essential for the family organisations that participated in this study to include these incentives in their programmes, thus motivating parents to attend. This might be impossible because of a lack of funds, which could impede effective preventative family preservation and could mean that statutory services might have to be rendered.

\section{Crisis management, statutory work, therapeutic services enjoy priority}

Only seven of the respondents stated that it was essential to render crisis management, statutory and certain therapeutic services regularly and that there was not sufficient time to spend on preventative services. In the words of one correspondent: "As a result of large work loads social workers do not always reach clients to render preventative services." ["As gevolg van hoë werkladings kom maatskaplike werkers nie altyd by kliënte uit om voorkomingsdienste te lewer nie."]

Another correspondent noted: "Social workers are too caught up in services that require individual work." ["Maatskaplike werkers word te vasgevang in dienste wat individuele werk behels."]

It can be deduced that respondents in this study felt that, as a result of the strong emphasis on casework or counselling services, there was insufficient time to spend on preventative service delivery in terms of initiating community work programmes. This confirms Streak and Poggenpoel's (2005:4) contention that, because of the lack of finances in NGOs, service delivery could not be expanded.

\section{Preventative services are feasible}

A small number (5) of respondents noted that the requirement that service delivery should be focused mainly on preventative services was feasible in their work situation, on condition that networking took place and much overtime work was put in. One respondent remarked that "...it is a reality within this organisation, but requires much overtime work and walking the 
extra mile." [“...dit is binne hierdie organisasie wel 'n werklikheid, maar verg baie oortyd en die ekstra myl loop."] The fact that these workers felt that much overtime work would be necessary for implementation of the policy requirements also pointed to a shortage of people power as respondents could not be expected to work overtime on a regular basis in order to comply with policy requirements.

\section{The ways in which work could be done in a more preventative way}

The focus group mentioned the ways in which the work could be done in a more preventative way. Members of the group were asked how they could work in a more preventative way to avoid an excessive emphasis on statutory services, as is required in policy documents. The subthemes and categories that emerged are presented in Table 1.

TABLE 1

\section{SUB-THEMES AND CATEGORIES REGARDING WAYS IN WHICH THE WORK COULD BE DONE IN A MORE PREVENTATIVE WAY}

\begin{tabular}{|l|l|}
\hline \multicolumn{2}{|c|}{ THEME: WAYS IN WHICH WORK COULD BE DONE IN A MORE } \\
PREVENTATIVE WAY
\end{tabular}

Table 1 shows that the themes that emerged from the focus group tie in strongly with the reasons, already discussed in the previous section, given by respondents to explain why more preventative work was not done.

\section{More people power is needed}

The first sub-theme was that more people power is needed to render mainly preventative services. The categories that were identified are firstly that statutory work enjoyed priority, confirming an earlier finding in this study that statutory services received the most emphasis in service delivery.

The two subsequent categories were that work loads were too heavy and that additional staff, such as community workers, was needed to render preventative services. The fact that additional staff members (community workers) should be utilised to render preventative services was emphasised by focus group members as well as respondents in this study. The 
reasons were not determined, but might be related to the heavy case loads that limit the time for preventative service delivery. It is also possible that casework and therapeutic or counselling services were regarded as a task rather to be done by social workers whereas other staff such as, for example, community developers were considered suitable by the study group to render preventative or community work services.

These perspectives of the participants of the focus group correspond with the earlier findings in this study regarding the obstacles that hamper preventative service delivery, as well as the respondents' opinions on the feasibility of preventative services in accordance with the policy guidelines.

\section{Limit turnover of social workers}

A further sub-theme mentioned by correspondents was that the turnover of social workers had to be limited as this affected the delivery of preventative services. In terms of the different categories the opinion was expressed that the difference in salaries between social workers in state employ and those working for NGOs should be resolved as the NGO sector found it difficult to retain experienced social workers because of this difference. The high turnover in staff also put more stress on experienced social workers as vacant posts increased their work load. This work load was also increased as tasks such as the field instruction of students were also allocated to more experienced workers. These opinions of the focus group members corresponded with the findings of Streak and Poggenpoel (2005:41), where NGOs also reported a turnover in personnel as a result of differences in salaries causing social workers to leave the organisations after having acquired experience.

\section{Better co-operation between the Department and NGOs, and between government departments}

Another sub-theme was that better co-operation was needed between NGOs and the Department of Social Development, as well as between the different state departments, as this could have a positive effect on the delivery of preventative services. In this regard members of the focus group especially pointed out the administrative requirements of the Department of Social Development in terms of time-consuming progress reports. Focus group members held the view that interdepartmental liaison could be improved. Although this aspect did not strictly point to a way in which work could be done in a more preventative manner, the sentiment of two of the focus group members was that the administrative requirements were time consuming and that valuable time for preventative work was lost.

\section{Network development}

The last sub-theme to emerge was the development of networks in a community. The importance of developing networks to render preventative services was also mentioned by some respondents as an important way in which such services could in fact be delivered. The categories in this sub-theme were that relations with other community resources should be maintained so that co-operation regarding preventative services could be improved. Empowering the appropriate community resources with knowledge also seemed to be a way to work more preventatively.

The narratives of the members of the focus group regarding the above sub-themes and categories are presented in Table 2 . 
TABLE 2

NARRATIVES OF FOCUS GROUP MEMBERS ABOUT WAYS IN WHICH WORK COULD BE DONE IN A MORE PREVENTATIVE WAY

\section{Sub-theme and} categories

\section{Narratives}

Sub-theme:Greater people power required

Categories: $\quad$ - "You can plan this wonderful day (for community work) and then the hospital

1. Statutory phones and you have to do a Form 4, and then you have to do it." ["Jy kan work enjoys $\quad$ hierdie wonderlike dag beplan (vir gemeenskapswerk) en hierso bel die hospitaal priority $\quad$ en jy moet 'n Vorm 4 doen, en dan moet jy dit gaan doen."']

2. Work load is - "These projects and these things that you have to do require much planning and too heavy $\quad$ it needs a person who can focus only on this and who can plan projects without interruptions and without any crises". ["Hierdie projekte en hierdie goed wat jy doen verg baie beplanning en dit kort " $n$ persoon wat net hierop fokus en beplan en projekte uitwerk, sonder onderbrekings, sonder enige krisisse."]

3. Need commu- - "I think we should get more community developers, so that you can focus on the nity workers for preventative services things that you must focus on and the projects can then be managed by the community workers, so that the preventative work can also get going." [Ek dink 'n mens moet meer gemeenskapsontwikkelaars kry, sodat jy kan fokus op die goed waarop jy moet fokus, en die projekte dan deur die gemeenskapsontwikkelaars gehanteer word, sodat die voorkomende werk ook meer aan die gang kan kom.”]

\section{Sub-theme: Limit turnover of social workers}

\section{Categories:}

1. Differences in salaries between state and NGO social workers should be eliminated
"I think the state must take over the salaries of the NGOs, so that there are no salary differences. This will limit turnover. Then the organisation will not have to worry about salaries because the state says we pay the social workers, the money that we give to you must be used for maintenance, stationery, cars, because it is a big headache." ["Ek dink die staat moet al die salarisse van die NGO's oorneem, dat daar nie die salaris verskille is nie, dan sal jy ook jou "turnover" beperk. Dan hoef die organisasie nie te worry oor salarisse, want die staat sê ons betaal die maatskaplike werkers, die geld wat ons vir julle gee, moet gaan vir instandhouding, skryfbehoeftes, karre, want dis nogals 'n groot kopseer."]

2. Retain experience in NGOs

"But this is

"But this is where the unfairness lies between the differences in salaries. Perhaps it will be better if the State pays all the salaries of the social workers in South Africa, then you will possibly retain the experience (in the NGOs)."

["Maar dis waar die hele onregverdigheid uitkom oor die verskille in salarisse. Dis dalk beter as jy sê die staat betaal al die maatskaplike werkers in SuidAfrika, dan gaan jy dalk ook die ervaring (in die NGO's) behou."]

3. Turnover increases the workload of more experienced social workers
"We have had a vacant post again for three months now and this definitely has an impact, because now we must do it and now we are just really putting out fires." ["Ons sit dan nou weer drie maande met 'n vakante pos en dit het definitief 'n impak, want nou moet ons dit doen en dit is dan nou rêrig net vure doodslaan."'] 
Sub-theme: Better co-operation between Department and NGOs

\begin{tabular}{l|ll} 
Categories: & - "A lot of our time is spent on service plans, hours and hours, and then we are not \\
\hline
\end{tabular}

1. Restrict funded for it, for all these hours and every quarter we must hand in an unnecessary evaluation to the state, that is about what we have achieved with the service administrative plan. Really a lot of unnecessary time is wasted on what the state expects from duties $\quad y o u$... and if you don't do it, you are not keeping your side of the agreement, and so you will not get your money." ["Baie van ons tyd gaan in diensplanne in, ure en ure en dan word ons nie befonds daarvoor nie, vir al daai ure nie en elke kwartaal moet ons 'n evaluering vir die staat indien, dis wat ons bereik het met die diensplan, daar is regtig baie onnodige tyd wat ingaan in goed wat die staat van jou verwag ... doen jy dit nie, beteken dit jy kom nie jou kant van die ooreenkoms na nie, so jy kry nie jou geld nie."]

2. Improve inter- - "You get the impression that there is no interdepartmental liaison, not between departmental liaison welfare and education, not between justice and community safety. These people do not communicate at all, their legislation is contradictory." ["Jy kry die idee daar is geen interdepartementele skakeling nie, nie tussen welsyn en onderwys nie, nie tussen justisie en gemeenskapsbeveiliging nie. Erens kommunikeer hierdie mense glad nie, wetgewing weerspreek mekaar.”]

\section{Sub-theme: Network development}

\begin{tabular}{|c|c|}
\hline $\begin{array}{l}\text { Categories: } \\
\text { 1. Maintaining re- } \\
\text { lationships with } \\
\text { other communi- } \\
\text { ty resources }\end{array}$ & $\begin{array}{l}\text { - "Strong networks must be developed, I think all the available resources must be } \\
\text { utilised and strong relationships must be maintained with other resources." } \\
\text { ["Sterk netwerke moet ontwikkel word, ek dink jy moet al die bronne wat jy tot } \\
\text { jou beskikking het, gebruik en veral verhoudings reghou met die ander bronne."] }\end{array}$ \\
\hline $\begin{array}{l}\text { 2. Empower } \\
\text { community } \\
\text { resources }\end{array}$ & $\begin{array}{l}\text { "...then I started with another approach, where we now rather empower } \\
\text { community resources with knowledge, so we approach the churches, the police, } \\
\text { the clinic and we empower them to share this knowledge. So when the police } \\
\text { presented a project all the irresponsible parents were there. So our approach is } \\
\text { to empower the role-players so that they can transfer knowledge." [“... toe het ek } \\
\text { met 'n ander benadering begin, waar ons nou liewer gemeenskapsbronne binne } \\
\text { die gemeenskap bemagtig met kennis, so ons nader nou die kerke, die polisie, die } \\
\text { kliniek en ons bemagtig nou vir hulle om daardie kennis oor te dra, byvoorbeeld, } \\
\text { toe die polisie 'n projek aanbied, toe was al die onverantwoordelike ouers daar, } \\
\text { so ons benadering is om maar liewers die rolspelers te bemagtig, sodat hulle dan } \\
\text { die kennis oordra."] }\end{array}$ \\
\hline
\end{tabular}

From Table 2 it can be seen that the views of the focus group members regarding the way in which preventative services can be rendered in order to avoid statutory services correlated with the opinions of the respondents at the family welfare organisations involved in this study.

\section{DISCUSSION}

Regarding the perspective of social workers on the implementation of family preservation services with a focus on prevention in accordance with policy documents, it seems that the study group and the members of the focus group were of the opinion that the strongest emphasis in service delivery was still on statutory work, then on early intervention and lastly on preventative services. Services are therefore rendered in inverse order to what the policy documents (Department of Social Development, 2006a:29; Ministry for Welfare and Population Development, 1997) recommend. This situation means that the desired paradigm 
shift in social work services - from the strong emphasis on statutory services before 1994 to preventative services - at the three family organisations involved in this study has not yet taken place effectively.

Perspectives on the obstacles to family preservation services were found to be a shortage of social workers, as well as a shortage of funds to initiate and maintain projects. Insufficient resources such as vehicles at the organisations and in the community were also pointed out as obstacles. It can be concluded that the family welfare organisations involved in this study did not have sufficient funding to appoint more workers or to initiate and maintain projects, thus seriously hampering the implementation of policy requirements regarding preventative service delivery.

Preventative service delivery in accordance with the requirements of the policy documents was, according to social workers, not feasible. Reasons put forward were that the limited resources available in communities for families affected the delivery of preventative services. Where resources were available, it seemed that the financial implications put them beyond the reach of these families. The heavy work loads of social workers were another aspect hampering preventative service delivery. The high turnover of social workers as well as the fact that community work and casework services were often done by the same worker were also factors named. Another factor that influenced the execution of the policy was the lack of funds in the organisation to maintain programmes.

Opinions on how to work in a more preventative way correlated with the reasons why work could not be done in this way - for example, that statutory work impacted on the time that was available for prevention services. Another aspect which emerged was the fact that salaries of social workers at NGOs should be fully subsidised by the state in order to restrict the turnover of social workers and to retain the experience of social workers at the NGOs.

The opinion of both the respondents and the focus group members was that social workers should render the casework or early intervention services, while other staff members such as social workers, auxiliary workers and community developers should be appointed to develop and render developmental preventative or community work services.

\section{CONCLUSIONS}

The following conclusions are drawn:

The implementation of the stipulations in policy documents (Department of Social Development, 2006) in terms of developmental social work services, with the emphasis on preventative family preservation services, could only take place should more staff be made available, as the emphasis in service delivery is still on statutory services. If the manpower shortage is not addressed, preventative or community work services cannot be expanded and the emphasis in service delivery will remain on statutory services, as organisations do not have the financial means to increase their people power themselves. The recommendation already made in other studies that statutory services should be fully financed (100\%), so that funds acquired from donors can be used for preventative services, is supported.

Casework services (early intervention or therapeutic services) should be rendered separately from community work services (preventative family preservation services) if case loads are heavy. The urgency of family needs and problems seems to hamper the initiation and development of preventative services. If case loads are lighter, it could well be possible to render case, group and community work services. 
Social workers, child care workers and community developers could be used to render preventative services, but these workers should be fully subsidised, as child and family welfare organisations do not have the financial means to afford these salaries without the support of the government.

The differences between the salaries of social workers working for the state as opposed to those working for NGOs should be addressed urgently, because the turnover of social workers as a result of this difference affects continuity in service rendering. Expertise in NGOs is also lost in this way and pressure is put on the remaining workers as a result of the turnover.

This study again confirms that the rendering of family preservation services by child and family welfare organisations, specifically with a focus on prevention, is virtually impossible because of structural obstacles such as heavy case loads and insufficient people power. As a result statutory services are numerous and children are removed from their parents, because families have too little access to preventative services or resources. Family welfare organisations, furthermore, do not have the financial means to address the lingering people power shortage. If this situation is not addressed by the government, NGOs cannot be held responsible for the fact that the paradigm shift to developmental preventative social services is not taking place.

\section{REFERENCES}

BELL, M. 2005. Community-based parenting programmes: an exploration of the interplay between environmental and organizational factors in a Webster Stratton project. British Journal of Social Work, 37(1):55-72.

BROWN, M. \& NEKU, R.J. 2005. A historical review of the South African social welfare system and social work practitioners' views on its current status. International Social Work, 48(3):301-312.

COULTON, C.J., KORBIN, J.E. \& SU, M. 1999. Neighbourhoods and child maltreatment: a multilevel study. Child Abuse \& Neglect, 23(11):1019-1039.

DE VOS, A.S., STRYDOM, H., FOUCHÉ, C.B. \& DELPORT, C.S.L. 2002. Research at grass roots: for the social sciences and human service professions $\left(2^{\text {nd }} \mathrm{ed}\right)$. Pretoria: Van Schaik Publishers.

DEPARTMENT OF SOCIAL DEVELOPMENT. 2005. National Policy Framework and Strategic Plan for the Prevention and Management of Child Abuse, Neglect and Exploitation. Pretoria.

DEPARTMENT OF SOCIAL DEVELOPMENT. 2006. Integrated Service Delivery Model for Developmental Social services. Pretoria.

FOUCHÉ, C.B \& DE VOS, A.S. 2005. Quantitative research designs. In: DE VOS, A.S., STRYDOM, H., FOUCHÉ, C.B. \& DELPORT, C.S.L. Research at grass roots: for the social sciences and human service professions ( $3^{\text {rd }}$ ed). Pretoria: Van Schaik Publishers: 132-143.

GARBARINO, J. \& KOSTELNY, K. 1992. Child maltreatment as a community problem. Child Abuse \& Neglect, 16(4):455-464.

GRINNELL, R.M. \& WILLIAMS, M. 1990. Research in social work: a primer. Itasca, Ill.: F.E. Peacock.

GRINNELL, R.M. 1988. Social work research and evaluation. Itasca, Ill.: F.E. Peacock. 
HOCHFELD, T. 2007. Missed opportunities: conservative discourses in the draft National Family Policy of South Africa. International Social Work, 50(1):79-91.

KRUGER, S.P. 1996. Intensiewe gesinsinstandhoudingsdienste: riglyne vir 'n maatskaplikewerk-model ter voorkoming van substituutsorg. Stellenbosch: University of Stellenbosch. (PhD Dissertation)

LOMBARD, A. 2007. The impact of social welfare policies on social development in SouthAfrica: an NGO perspective. Social Work/Maatskaplike Werk, 43(4):295-316.

LOMBARD, A. \& KLEIJN, W.C. 2006. Statutory social services: an integral part of developmental social welfare service delivery. Social Work/Maatskaplike Werk, 42(3/4):213-233.

MINISTRY FOR WELFARE AND POPULATION DEVELOPMENT. 1997. Whitepaper for Social Welfare. Government Gazette, 386 (18166). Pretoria, 8 August.

NICHOLSON, B.C., BRENNER, V. \& FOX, R.A. 1999. A community-based parenting program with low-income mothers of young children. Families in Society: The Journal of Contemporary Human Services, 80(3):247-253.

PECORA, J., FRASER, M.W., NELSON, K.E., McCROSKEY, J. \& MEEZAN, W. 1995. Evaluating family based services. New York: Hawthorne.

RUBIN, A. \& BABBIE, E. 2007. Essential research methods for social work. California: Thomson Brooks/Cole.

SANDERS, M. \& CANN, W. 2002. Promoting positive parenting as an abuse prevention strategy. In: BROWNE, K., HANKS, H., STRATTON, P. \& HAMILTON, C. Early prediction and prevention of child abuse: a handbook. Chichester: John Wiley and Sons, Ltd.: 145-163.

SEPTEMBER, R. \& BLANKENBERG, C. 2004. A quest for excellence in multidisciplinary child protective services: an exploratory review. Cape Town: Child and Youth Research and Training Programme, University of the Western Cape, Printwize.

SEPTEMBER, R.L. 2006. The progress of child protection in South Africa. International Journal of Social Welfare, 15(1):65-72.

SEPTEMBER, R.L. 2007. Separating social welfare services and social welfare grants: challenges and opportunities. Social Work/Maatskaplike Werk, 43(2):93-105.

SEWPAUL, V. 2001. Models of intervention for children in difficult circumstances in South Africa. Child Welfare, LXXX(5):571-586.

STREAK, J. \& POGGENPOEL, S. 2005. Towards social welfare services for all vulnerable children in South Africa: a review of policy development, budgeting and service delivery. Children's Budget Unit, Budget Information Service, Idasa. 31 Maart 2005.

STRYDOM, H. 2005. Sampling and sampling methods. In: DE VOS, A.S., STRYDOM, H., FOUCHÉ, C.B. \& DELPORT, C.S.L. Research at grass roots: for the social sciences and human service professions $\left(3^{\text {rd }}\right.$ ed). Pretoria: Van Schaik Publishers: 192-204.

TRACY, E.M. 1995. Family preservation and home-based services. Encyclopedia of Social Work $\left(19^{\text {th }}\right.$ ed $)$. Washington: NASW Press. 
WEYERS, M., STRYDOM, H. \& HUISAMEN, A. 2008. Trangulation in social work research: the theory and examples of its practical application. Social Work/Maatskaplike Werk, 44(2):207-222.

Dr Marianne Strydom, Department of Social Work, University of Stellenbosch, Stellenbosch, South Africa. 